\title{
KEBIASAAN BELAJAR SISWA DITINJAU DARI HASIL BELAJAR SERTA IMPLIKASINYA TERHADAP PELAYANAN BIMBINGAN DAN KONSELING
}

\author{
Rahmi Dwi Febriani \\ amidwifebriani@gmail.com \\ Universitas Negeri Padang \\ Triyono \\ triyonompd@gmail.com \\ STKIP PGRI Sumatera Barat
}

\begin{abstract}
Each student has different potential and ability in learning for which they are expected to be able to achieve the learning goals optimally. One of the factors affected the students achievement in learning habits. The fact in the field signified that the student have poor learning habits in which they did not study well, used time ineffectively and did not do their assignments as they were expected. The aim of this research was to: (1) describe the learning habits of the student having high achievement in learning and also those having low achievement in learning and (2) examined differences in learning habits of the students having high achievement and those having low achievement in learning. The was a descriptive comparative research. The population of the research was consisted of 286 students in SMPN 29 Padang. The number of samples as much as 80 students were selected by stratified purposive random sampling technique. The result of the research indicated that there was a significant difference between learning habit of the students having high achievement in learning and those having low achievement in learning.
\end{abstract}

Keywords: Learning Habits, Learning Achievement

\section{PENDAHULUAN}

Belajar merupakan proses yang unik. Keunikan ini disebabkan karena keberagaman cara dan hasil belajar yang terjadi pada setiap siswa. Tidak semua siswa akan memperoleh pemahaman yang sama dalam belajar, hal ini akan menjadikan seseorang memperoleh hasil belajar dan perubahan tingkah laku yang berbeda-beda satu dengan lainnya.

Berhasil atau gagalnya siswa dalam pendidikan tergantung pada proses belajar mereka. Slameto (2010:82) mengungkapkan belajar adalah suatu proses usaha yang dilakukan individu untuk memperoleh suatu perubahan tingkah laku yang baru secara keseluruhan, sebagai hasil pengalaman individu itu sendiri dalam interaksinya dengan lingkungannya. Sejalan dengan itu, Witherington (dalam Aunurrahman, 2010:35) mengungkapkan belajar merupakan suatu perubahan 
di dalam kepribadian yang menyatakan diri sebagai suatu pola baru dari reaksi berupa kecakapan, sikap, kebiasaan, kepribadian atau suatu pengertian.

Keberhasilan perserta didik dalam menguasai pelajaran di sekolah salah satunya dapat dilihat dari hasil belajar yang diperoleh. Hasil belajar merupakan kemampuan yang dimiliki siswa setelah ia menerima pengalaman belajarnya (Sudjana, 2004:5). Dalam proses pembelajaran ada siswa yang memiliki hasil belajar yang tinggi dan hasil belajar yang rendah. Siswa dengan hasil belajar tinggi, maka mereka digolongkan berhasil dalam proses pendidikan, namun ada juga sebaliknya siswa yang hasil belajarnya rendah dianggap kurang berhasil dalam pendidikan/akademik. Hal ini tidak terlepas dari kebiasaan belajar siswa itu sendiri. Karena salah satu faktor yang mempengaruhi hasil belajar adalah kebiasaan belajar.

Hasil penelitian menunjukkan bahwa hasil belajar mempunyai korelasi positif dengan kebiasaan belajar atau study habit, yaitu semakin baik kebiasaan belajar siswa, akan semakin bagus hasil belajarnya (Magfirah et al., 2015; Rahmawati, Sudarma, \& Sulastri, 2014; Djaali, 2012). Kebiasaan merupakan tingkah laku yang cenderung selalu ditampilkan individu dalam menghadapi situasi atau kondisi tertentu. Sedangkan kebiasaan belajar merupakan cara atau teknik yang menetap pada diri siswa pada waktu menerima pelajaran, membaca buku, mengerjakan tugas, dan pengaturan waktu untuk menyelesaikan kegiatan (Djaali, 2012:128).

Sejalan dengan itu, Yusuf (2009:138) juga mengemukakan bahwa kebiasaan belajar merupakan perilaku (kegiatan) belajar yang relatif menetap, karena sudah berulang-ulang (rutin) dilakukan. Oleh karena itu, kebiasaan belajar sangat penting dalam proses pembelajaran, kebiasaan belajar merupakan segenap perilaku yang ditunjukkan dari waktu ke waktu dalam rangka pelaksanaan pembelajaran.

Namun kenyataan di lapangan, berdasarkan temuan penelitian Satriana (2011) mengemukakan bahwa 63,77\% siswa yang nilainya di bawah KKM memiliki kebiasaan belajar kurang baik, dimana mereka kurang disiplin dalam belajar, lalu jarang mengikuti kegiatan belajar dengan baik, cara belajar yang kurang tepat, penggunaan waktu belajar yang tidak efektif, kurang mempersiapkan diri menghadapi ujian serta jarang mengerjakan tugas/pekerjaan rumah (PR). Hal ini akan berdampak pada pencapaian hasil belajar siswa.

Berdasarkan uraian di atas, maka penelitian ini bertujuan untuk mendeskripsikan kebiasaan belajar siswa ditinjau dari hasil belajarnya, serta menguji perbedaan kebiasaan belajar siswa ditinjau dari hasil belajar tinggi dan hasil belajar rendah.

\section{METODOLOGI PENELITIAN}

Penelitian ini menggunakan metode penelitian kuantitatif (Creswell, 2013) dengan jenis penelitian deskriptif komparatif (Yusuf, 2016), Populasi penelitian ini adalah siswa SMP Negeri 29 Padang kelas VIII yang berjumlah 286 orang. Jumlah sampel penelitian sebanyak 80 siswa dipilih dengan dengan cara Stratified purposive random sampling (pengambilan sampel secara acak dengan tujuan atau karakteristik tertentu).

Instrumen yang digunakan dalam penelitian ini berupa skala kebiasaan belajar. Data penelitian dianalisis menggunakan statistik deskriptif dengan teknik persentase dan t-test, sesuai dengan tujuan penelitian. 


\section{HASIL PENELITIAN}

\section{Deskripsi Data}

Data dalam penelitian ini meliputi variabel kebiasaan belajar dan hasil belajar. Berikut ini dikemukakan deskripsi data hasil penelitian.

\section{Deskripsi Data Kebiasaan Belajar Siswa Ditinjau dari Hasil Belajar}

Deskripsi data kebiasaan belajar siswa secara keseluruhan ditinjau dari hasil belajar tinggi dan hasil belajar rendah dapat dilihat pada tabel berikut ini.

Tabel 1. Deskripsi Kebiasaan Belajar Siswa Ditinjau dari Hasil Belajar secara Keseluruhan

\begin{tabular}{cccccc}
\hline & Interval & \multicolumn{1}{c}{$\begin{array}{c}\text { Hasil } \\
\text { Belajar } \\
\text { Kategori }\end{array}$} & \multicolumn{2}{c}{$\begin{array}{c}\text { Hasil } \\
\text { Belajar } \\
\text { Singgi }\end{array}$} & \multicolumn{2}{c}{$\begin{array}{c}\text { Rendah } \\
\text { Skor }\end{array}$} & & \begin{tabular}{c} 
T \\
\cline { 3 - 6 }
\end{tabular} & $\mathbf{\text { f }}$ & $\mathbf{\%}$ \\
Sangat Baik (SB) & $\geq 266$ & 8 & 20 & 0 & 0 \\
Baik (B) & $204-265$ & 27 & 68 & 18 & 45 \\
Cukup Baik (CB) & $142-203$ & 5 & 12 & 20 & 50 \\
Kurang Baik (KB) & $\leq 141$ & 0 & 0 & 2 & 5 \\
Keseluruhan & & $\mathbf{4 0}$ & 100 & $\mathbf{4 0}$ & 100 \\
\hline
\end{tabular}

Berdasarkan Tabel 1 dapat dilihat bahwa secara keseluruhan kebiasaan belajar siswa yang hasil belajarnya tinggi lebih baik dibandingkan dengan siswa yang hasil belajarnya rendah.

Tabel 2. Deskripsi Kebiasaan Belajar Siswa dalam Mengatur Jadwal Belajar

\begin{tabular}{cccccc}
\hline \multirow{2}{*}{ Kategori } & $\begin{array}{c}\text { Interval } \\
\text { Skor }\end{array}$ & $\begin{array}{c}\text { Hasil } \\
\text { Belajar } \\
\text { Tinggi }\end{array}$ & \multicolumn{2}{c}{$\begin{array}{c}\text { Hasil } \\
\text { Belajar } \\
\text { Rendah }\end{array}$} \\
\cline { 3 - 6 } Sangat Baik (SB) & $\geq 266$ & 7 & 18 & 5 & 13 \\
Baik (B) & $204-265$ & 30 & 75 & 17 & 42 \\
Cukup Baik (CB) & $142-203$ & 3 & 7 & 16 & 40 \\
Kurang Baik (KB) & $\leq 141$ & 0 & 0 & 2 & 5 \\
\hline
\end{tabular}

Tabel 2 memperlihatkan bahwa pada umumnya siswa yang hasil belajar rendah masih kurang baik kebiasaan belajarnya dalam mengatur jadwal belajar sekitar (40\%).

Tabel 3. Deskripsi Kebiasaan Belajar Siswa dalam Mengikuti Pelajaran di Kelas

\begin{tabular}{cccccc}
\hline \multirow{2}{*}{ Kategori } & $\begin{array}{c}\text { Interval } \\
\text { Skor }\end{array}$ & $\begin{array}{c}\text { Hasil } \\
\text { Belajar } \\
\text { Tinggi }\end{array}$ & \multicolumn{2}{c}{$\begin{array}{c}\text { Hasil } \\
\text { Belajar } \\
\text { Rendah }\end{array}$} \\
\cline { 3 - 6 } & & f & $\%$ & f & $\%$ \\
Sangat Baik (SB & $\geq 266$ & 5 & 13 & 2 & 5 \\
Baik (B) & $204-265$ & 26 & 65 & 23 & 57 \\
Cukup Baik (CB) & $142-203$ & 9 & 22 & 15 & 38 \\
Kurang Baik (KB) & $\leq 141$ & 0 & 0 & 0 & 0 \\
\hline
\end{tabular}

Berdasarkan Tabel 3 dapat dilihat bahwa kebiasaan belajar siswa yang hasil belajarnya tinggi sangat baik dalam mengikuti pelajaran di kelas dibanding siswa yang hasil belajarnya rendah.

Tabel 4. Deskripsi Kebiasaan Belajar Siswa dalam Membaca dan Membuat Catatan

\begin{tabular}{cccccc}
\hline \multirow{2}{*}{ Kategori } & $\begin{array}{c}\text { Interval } \\
\text { Skor }\end{array}$ & $\begin{array}{c}\text { Hasil } \\
\text { Belajar } \\
\text { Tinggi }\end{array}$ & \multicolumn{2}{c}{$\begin{array}{c}\text { Hasil } \\
\text { Belajar } \\
\text { Rendah }\end{array}$} \\
\cline { 3 - 6 } Sangat Baik (SB & $\geq 266$ & 9 & 23 & 2 & 5 \\
Baik (B) & $204-265$ & 23 & 57 & 19 & 48 \\
Cukup Baik (CB) & $142-203$ & 8 & 20 & 13 & 32 \\
Kurang Baik (KB) & $\leq 141$ & 0 & 0 & 6 & 15 \\
\hline
\end{tabular}

Tabel 4 memperlihatkan bahwa pada umumnya siswa yang hasil belajar rendah masih kurang baik kebiasaan belajarnya dalam membaca dan membuat catatan (32\%). 
Tabel 5. Deskripsi Kebiasaan

Belajar Siswa dalam Mengulang Bahan Pelajaran

\begin{tabular}{cccccc}
\hline \multirow{2}{*}{ Kategori } & $\begin{array}{c}\text { Interval } \\
\text { Skor }\end{array}$ & $\begin{array}{c}\text { Hasil } \\
\text { Belajar } \\
\text { Tinggi }\end{array}$ & $\begin{array}{c}\text { Hasil } \\
\text { Belajar } \\
\text { Rendah }\end{array}$ \\
\cline { 3 - 6 } & & $\mathbf{f}$ & $\%$ & f & $\%$ \\
Sangat Baik (SB & $\geq 266$ & 4 & 10 & 0 & 0 \\
Baik (B) & $204-265$ & 18 & 45 & 14 & 35 \\
Cukup Baik (CB) & $142-203$ & 17 & 42 & 21 & 52 \\
Kurang Baik (KB) & $\leq 141$ & 1 & 3 & 5 & 13 \\
\hline
\end{tabular}

Berdasarkan Tabel 5 dapat dilihat bahwa kebiasaan belajar siswa yang hasil belajarnya tinggi sangat baik dalam mengulang bahan dibanding siswa yang hasil belajarnya rendah.

Tabel 6. Deskripsi Kebiasaan Belajar Siswa dalam Mengerjakan Tugas

\begin{tabular}{cccccc}
\hline Kategori & $\begin{array}{c}\text { Interval } \\
\text { Skor }\end{array}$ & $\begin{array}{c}\text { Hasil } \\
\text { Belajar } \\
\text { Tinggi }\end{array}$ & $\begin{array}{c}\text { Hasil } \\
\text { Belajar } \\
\text { Rendah }\end{array}$ \\
\cline { 3 - 6 } & & $\mathbf{f}$ & $\%$ & f & $\%$ \\
Sangat Baik (SB & $\geq 266$ & 13 & 33 & 0 & 0 \\
Baik (B) & $204-265$ & 25 & 62 & 25 & 62 \\
Cukup Baik (CB) & $142-203$ & 2 & 5 & 13 & 33 \\
Kurang Baik (KB) & $\leq 141$ & 0 & 0 & 2 & 5 \\
\hline
\end{tabular}

Tabel 6 memperlihatkan bahwa pada umumnya siswa yang hasil belajar rendah masih kurang baik kebiasaan belajarnya dalam mengerjakan tugas (38\%).

\section{Menguji Perbedaan Kebiasaan Belajar Siswa Ditinjau dari Hasil Belajar}

Hasil pengujian hipotesis perbedaan kebiasaan belajar siswa ditinjau dari hasil belajar dapat dilihat pada Tabel 7 berikut ini.

\section{Tabel 7. Perbedaan Kebiasaan Belajar Siswa Ditinjau dari Hasil Belajar}

\begin{tabular}{|c|c|c|c|c|c|c|}
\hline \multicolumn{2}{|c|}{ Variabel } & Mean & Sig. & $\mathbf{t}_{\text {hitung }}$ & $\mathbf{t}_{\text {tabel }}$ & $\begin{array}{cc}\text { Sig. } & \text { Ket } \\
\text { :-tailed) } & .\end{array}$ \\
\hline \multirow[t]{2}{*}{$\begin{array}{l}\text { Hasil } \\
\text { Belajar }\end{array}$} & Tinggi & 40235,65 & 0,426 & 4,230 & 2,021 & $\begin{array}{c}\text {,000 } \\
\begin{array}{c}\text { Signifi } \\
\text {-kan }\end{array}\end{array}$ \\
\hline & Rendah & 40208,15 & & & & \\
\hline
\end{tabular}

Tabel 7 memperlihatkan bahwa diperoleh koefisien $P$-value sebesar 0,426 lebih besar dari $0.05(0,426>$ $0,05)$, berarti varians kelompok dinyatakan homogen. Dengan demikian persyaratan homogenitas untuk analisis komparasi terpenuhi.

Selanjutnya, dapat dilihat nilai signifikansi pada variabel hasil belajar siswa sebesar ,000. Sesuai dengan kriteria pengujian hipotesis melalui $t$ test, jika signifikansi $(, 000)$ lebih kecil dari 0,05 atau $t_{\text {hitung }}$ lebih besar dari $t_{\text {tabel }}$ $(4,230 \geq 2,021)$ dengan taraf signifikansi 0,05 , artinya terdapat perbedaan yang signifikan antara kebiasaan belajar siswa yang hasil belajarnya tinggi dan hasil belajarnya rendah.

\section{PEMBAHASAN}

\section{Gambaran Kebiasaan Belajar Siswa Ditinjau dari Hasil Belajar}

Hasil analisis deskriptif menunjukkan bahwa kebiasaan belajar siswa dilihat dari hasil belajar tergolong baik. Hal ini menunjukkan bahwa secara umum siswa telah memiliki kebiasaan belajar baik, siswa yang memiliki kebiasaan belajar yang baik cenderung hidup dengan penuh disiplin dan tanggung jawab dalam setiap tindakan belajarnya untuk mencapai prestasi dan hasil belajar yang tinggi (Siagian, 2012). Sejalan 
dengan itu, study habit improve prediction of academic performance more than any other noncognitive individual difference variable examined to date and should be regarded as the pillar of academic success (Sakaluk, Williams, \& Biernat, 2014).

a. Kebiasaan dalam Mengatur Jadwal Belajar

Keberhasilan belajar siswa dalam proses belajar salah satunya tercermin dari hasil belajar yang diperolehnya. Hal itu tentunya tidak terlepas dari rencana belajar yang telah disusun siswa sebelumnya. Tabrani (2005:58) mengemukakan bahwa belajar memerlukan perencanaan yang baik agar kita bisa menggunakan waktu yang ada seefktif dan seefesien mungkin, selain itu perencanaan juga berfungsi membimbing diri kita agar waktu itu digunakan seproduktif mungkin. Djamarah (2011:26) mengatakan orang yang pandai membagi dan memanfaatkan waktu untuk kepentingan studi selama menuntut ilmu, dialah orang yang beruntung hari ini, esok, dan mendatang.

Sejalan dengan itu, Slameto (2010:82) jadwal berpengaruh terhadap belajar, agar belajar dapat berjalan dengan baik dan berhasil perlulah seseorang siswa mempunyai jadwal yang baik dan melaksanakannya dengan teratur/disiplin.

\section{b. Mengikuti Pelajaran di Kelas}

Berdasarkan data yang disajikan menunjukkan bahwa kebiasaan belajar siswa yang hasil belajar tinggi dilihat dari aspek mengikuti pelajaran di kelas adalah $68 \%$ siswa dikategorikan baik. Kebiasaan mengikuti pelajaran seorang siswa dianggap baik apabila ia memiliki sikap dan pandangan yang positif terhadap proses belajaranya. Sikap dan pandangan positif tersebut dapat mempengaruhi kegairahan, kemauan, keinginan, ketertarikan, dan aktifitas siswa berkenaan dengan pelajaran yyang diikutinya sehingga siswa memperoleh pengetahuan, pemahaman, dan wawasan (Triyono Triyono \& Febriani, 2018b).

Hal ini senada dengan pendapat Prayinto (2002:5) agar kegiatan menjalani proses belajar berlangsung secara efektif, siswa perlu memiliki pandangan dan sikap yang positif terhadap pembelajaran yang diikutinya. Apabila sikap dan pandangan positif tersebut dimiliki dan diterapkan oleh siswa kemungkinan akan memperoleh hasil belajar yang memuaskan, sebaliknya bila berbagai kondisi yang diharapkan tidak dimiliki siswa, maka kemungkinan akan mengalami gangguan dan hambatan dalam kegiatan belajar. Sedangkan menurut Slameto (2010:76) menyatakan belajar yang efesien dapat dicapai apabila menggunakan strategi belajar yang tepat untuk dapat mencapai hasil belajar yang maksimal. Oleh sebab itu, dalam mengikuti proses belajar siswa hendaknya memiliki sikap positif terhadap belajar yang diikutinya dan memiliki berbagai strategi belajar untuk meningkatkan hasil belajar (Febriani \& Triyono, 2018).

\section{c. Membaca dan Membuat Catatan}

Hasil penelitian terhadap kebiasaan belajar siswa hasil belajar tinggi dalam membaca dan membuat catatan dikategorikan baik, dan siswa hasil belajar rendah hanya $5 \%$ baik.

Menurut Slameto (2010:83) membaca besar pengaruhnya terhadap belajar, hampir sebagian besar kegiatan belajar adalah membaca. Agar dapat belajar dengan baik maka perlulah 
membaca dengan baik pula, karena membaca adalah alat belajar. Menurut Yamin (2010:106) membaca adalah suatu cara untuk mendapatkan informasi yang disampaikan secara verbal dan merupakan hasil ramuan pendapat, gagasan, teori-teori, hasil penelitian para ahli untuk diketahui dan menjadi pengetahuan siswa. Seorang siswa yang memiliki hobi membaca sudah merupakan modal dalam belajar, sebaliknya seorang siswa yang malas dalam membaca maka dia akan jauh dari pengetahuan.

Sejalan dengan itu, Gie (2002:23) membaca buku yang dilakukan siswa kebanyakan akan menjdi sia-sia kalau ia tidak membuat catatan dari bahan bacaannya, karena pikiran tidak dapat seketika mengingat begitu banyak butir pengetahuan tanpa berulang-ulang menghafalnya. Hal yang sebaiknya dilakukan siswa untuk mendapatkan hasil belajar yang baik, belajar yang sungguh-sungguh, dengan membuat catatan pada buku tertentu untuk masing-masing mata pelajaran. Menurut Thabrani (2005:76) format catatan yang baik dan lengkap akan membantu mempelajari atau mengulang pelajaran dengan cepat. Jadi dengan demikian jelaslah bahwa membuat catatan pelajaran dengan rapi dan lengkap dapat meningkatkan hasil belajar.

Selanjutnya, Prayitno (2002:23) mengemukakan bahwa siswa dapat mencatat hal penting secara jelas, dapat mencatat simpulan dari setiap bahasan, dan dapat mencatat makna dari materi yang dibahas. Untuk mencapai tujuan belajar yang maksimal, siswa mestinya memotivasi diri agar selalu berusaha untuk mencatat pelajarannya karena dengan mencatat akan membantu siswa mengingat kembali materi yang telah diterangkan guru. Tanpa mencatat dan mengulangi kemungkinan orang hanya mampu mengingat sebagian kecil materi yang dibaca.

\section{d. Mengulang Bahan Pelajaran}

Hasil data yang disajikan menunjukkan bahwa $45 \%$ siswa hasil belajar tinggi memiliki kebiasaan belajar siswa yang baik dilihat dari aspek mengulang bahan pelajaran dan siswa peringkat rendah dengan persentase 52\% katergori cukup baik.

Mengulang pelajaran adalah salah satu cara agar kegiatan belajar menguat dalam ingatan. Mengulang besar pengaruhnya dalam belajar, karena dengan adanya pengulangan (review) bahan yang belum begitu dikuasai serta mudah terlupakan akan tetap tertanam dalam otak seseorang. Agar dapat mengulang dengan baik maka perlulah kiranya disediakan waktu untuk mengulang dan menggunakan waktu itu sebaiksebaiknya, untuk menghafal dengan bermakna dan memahami bahan yang diulang secara sungguh-sungguh.

Menurut Slameto (2010:86) menghafal bahan dengan baik siswa hendaklah memperhatikan syarat-syarat sebagai berikut: a) menyadari sepenuhnya tujuan belajar, b) mengetahui betul-betul tentang makna bahan yang dihafal, c) mencurahkan perhatian sepenuhnya sewaktu menghafal, d) menghafal secara teratur sesuai kondisi badan yang sebaik-baiknya serta daya serap otak terhadap bahan yang harus dihafal.

\section{e. Mengerjakan Tugas}

Hasil penelitian terhadap kebiasaan belajar siswa peringkat tinggi dalam mengerjakan tugas dikategorikan baik yaitu $74,70 \%$, dan siswa peringkat rendah $66,25 \%$ dikategorikan baik. 
Menurut Prayitno (2002:8) salah satu faktor penentu kesuksesan siswa dalam belajar adalah sejauh mana siswa dapat menyelesaikan dengan baik tugas-tugas yang dituntut oleh guru. Tugas dalam setiap pembelajaran yang diikuti siswa bukan hanya sekedar dapat diselesaikan seadanya, tetapi hendaknya dapat memenuhi mutu dan kriteria yang diharapkan disamping dapat diselesaikan pada waktu yang ditetapkan.

Senada dengan itu, Slameto (2010:88) agar siswa berhasil dalam belajar perlu mengerjakan tugas-tugas dengan baik, dengan menyelesaikan tugas tepat waktu akan mengurangi kecemasan pada diri siswa. Suatu tugas dapat dikerjakan dengan baik dan dapat dikerjakan pada waktunya apabila ditunjang oleh materi atau bahan yang diperlukan. Untuk itu, kegiatan pertama siswa dalam mengerjakan tugas adalah mempersiapkan bahan-bahan atau materi dengan lengkap dan relevan. Materi dapat diperoleh dari berbagai sumber seperti: catatan pelajaran, kartu kutipan, tugas teman, buku perpustakaan, dibeli sendiri atau dipinjam dari guru (Prayitno, 2002:6).

Selanjuthya, dalam menyelesaikan tugas sekurang-kurangnya ada dua hal yang perlu diperhatikan yaitu: mutu tugas, waktu mengerjakan dan penyelesainya (Prayitno, 2002:8). Agar tugas dapat diselesaikan dengan mutu yang baik maka tugas tersebut perlu dikerjakan dalam waktu yang cukup, oleh karena itu perlu merencanakan waktu pengerjaan ataupun penyelesaian tugas tersebut.

\section{Perbedaan Kebiasaan Belajar Siswa Peringkat Tinggi dan Peringkat Rendah di SMP Negeri 29 Padang}

\begin{abstract}
Hasil temuan penelitian mengungkapkan bahwa terdapat perbedaan yang signifikan antara kebiasaan belajar siswa peringkat tinggi dan peringkat rendah di SMP Negeri 29 Padang. Ini berarti hipotesis dari penelitian terbukti atau diterima. Hal ini dibuktikan dari hasil data dengan melihat nilai $t$, maka diperoleh nilai t 3,060 dan nilai tabel signifikasi $5 \%$ adalah 2,021. Karena nilai t yang diperoleh adalah 3,060 sedangkan nilai $t_{\text {tabel }}$ adalah 2,021 maka nilai $t$ hasil lebih besar dari $t_{\text {tabel }}\left(t\right.$ hitung $\left.\geq t_{\text {tabel }}\right)$ sehingga terdapat perbedaan yang signifikasi.
\end{abstract}

Perbedaan ini dapat dilihat dari sub variabel kebiasaan mengikuti pelajaran siswa peringkat tinggi dan rendah, persentase yang cenderung tinggi ditempati siswa peringkat tinggi. Kebiasaan mengikuti pelajaran siswa dianggap baik apabila ia memiliki sikap dan pandangan positif terhadap proses belajar. Belajar yang efesien dapat dicapai apabila menggunakan strategi belajar yang tepat untuk dapat mencapai hasil belajar yang maksimal (Slamet, 2010; Febriani, Ardi, \& Handayani, 2018; Febriani, Yusuf, \& Iswari, 2016).

Berbedanya kebiasaan belajar siswa peringkat tinggi dan peringkat rendah bisa saja disebabkan oleh beberapa faktor antara lain: kemampuan bawaan, kondisi fisik orang yang belajar, kondisi psikis anak, kemauan belajar, sikap terhadap guru, mata pelajaran dan pengertian mereka mengenai kemajuan mereka sendiri serta bimbingan. Prestasi belajar yang diraih siswa merupakan hasil interaksi banyak faktor dalam diri maupun faktor dari luar diri siswa tersebut (Tri Triyono, 2017). Salah satu faktor yang 
mempengaruhi prestasi belajar adalah kebiasaan belajar.

Kebiasaan belajar adalah kegiatan belajar yang ditempuh seharihari di luar kegiatan belajar di sekolah atau selama mengikuti proses belajar mengajar termasuk di dalamnya metode belajar yang digunakan, cara belajar, dan penggunaan waktu untuk belajar. Djaali (2012:128) mengemukakan kebiasaan belajar merupakan cara atau teknik yang menetap pada diri siswa pada waktu menerima pelajaran, membaca buku, mengerjakan tugas, dan pengaturan waktu untuk menyelesaikan kegiatan. Siswa yang mempunyai kebiasaan belajar baik akan memperoleh hasil belajar yang optimal dan sebaliknya kebiasaan belajarnya buruk akan memperoleh hasil belajar yang kurang optimal (Triyono Triyono \& Febriani, 2018a).

Kebiasaan belajar yang baik menentukan kesuksesan seseorang. Slameto (2010:82) mengungkapkan kebiasaan belajar diperoleh dengan cara-cara yang dipakai untuk mencapai tujuan belajar. Belajar bertujuan untuk mendapatkan pengetahuan, sikap, kecakapan, dan keterampilan, cara-cara yang dipakai itu akan menjadi kebiasaan. Siswa hendaknya dapat meningkatkan kebiasaan belajarnya, sehingga hasil belajar yang diperoleh semakin baik.

Berdasarkan paparan di atas, jelaslah bahwa perbedaan kebiasaan belajar siswa peringkat tinggi dan peringkat rendah berbeda. Perbedaan tersebut dapat dilihat dari sub variabel kebiasaan belajar dan hal-hal lain yang mempengaruhinya.

\section{KESIMPULAN DAN SARAN Kesimpulan}

Berdasarkan hasil analisis data yang telah dibahas pada bab terdahulu, dapat diambil kesimpulan sebagai berikut: (1) Kebiasaan belajar siswa dengan hasil belajar tinggi di SMP Negeri 29 Padang tergolong pada kategori baik yaitu sekitar 68\%, (2) Kebiasaan belajar siswa dengan hasil belajar rendah di SMP Negeri 29 Padang tergolong pada kategori cukup baik yaitu sekitar 50\% siswa. (3) Terdapat perbedaan antara kebiasaan belajar siswa dengan hasil belajar tinggi dan hasil belajar rendah di SMP Negeri 29 Padang. Hal ini berarti siswa dengan hasil belajar tinggi memiliki kebiasaan belajar yang baik dibandingkan siswa dengan hasil belajar rendah.

\section{Saran}

Berdasarkan hasil penelitian, maka penulis mengemukakan beberapa saran, yaitu: (1) diharapkan kepada siswa, khususnya siswa yang berada pada kategori cukup baik bahkan siswa yang berada pada kategori baik, hendaknya berusaha untuk memperbaiki serta meningkatkan kebiasaan belajar sehingga mempermudah mengikuti proses pembelajaran dengan baik dan mampu memperoleh hasil belajar yang memuaskan, (2) diharapkan kepada guru BK/konselor terus mengembangkan layanan bimbingan dan konseling dalam meningkatkan kebiasaan belajar siswa, seperti memberikan layanan informasi tentang kebiasaan belajar yang baik, layanan penguasaan konten dan layanan bimbingan kelompok yang terkait dengan kebiasaan mengatur jadwal belajar, mengikuti pelajaran di kelas, membaca dan membuat catatan, mengulang bahan pelajaran 
dan mengerjakan tugas serta berupaya memberikan layanan yang dapat membantu siswa dalam memperoleh hasil belajar yang baik, (4) peneliti selanjutnya, diharapkan dapat dijadikan sebagai dasar penelitian lanjutan dengan mengungkap dan

\section{DAFTAR RUJUKAN}

Aunurrahman. 2010. Belajar dan Pembelajaran. Bandung: Alfabeta.

Creswell, J. W. 2013. Research Design: Qualitative, quantitative, and mixed methods approaches. Sage publications.

Djaali. 2012. Psikologi Pendidikan. Jakarta: Bumi Aksara.

Djamarah, S. B. 2011. Psikologi Belajar. Jakarta: Rineka Cipta.

Gie, T. L. 2002. Cara Belajar yang Efisien. Yogyakarta: Gajah Mada

Febriani, R. D., Ardi, Z., \& Handayani, P. G. (2018). The Impact of Parents Education Level on Career Aspiration Enhancement.

Febriani, R. D., \& Triyono, T. (2018). Faktor Penghambat Pelaksanaan Evaluasi Program Bimbingan dan Konseling oleh Guru Bimbingan dan Konseling. Jurnal Counseling Care, 2(1), 21-27.

Febriani, R. D., Yusuf, A. M., \& Iswari, M. (2016). Perbedaan Aspirasi Karier Siswa ditinjau dari Jenis Kelamin, Jurusan, dan Tingkat Pendidikan Orangtua serta Implikasinya terhadap Pelayanan Bimbingan dan Konseling. Konselor, 5(3), 160 171. meneliti variabel lain serta penelitian pengembangan tentang peningkatan kebiasaan belajar siswa sehingga sukses dalam belajarnya dan mendapatkan hasil belajar yang optimal.

Magfirah, I., Rahman, U., Sulasteri, S., Selayar, B. K., Belajar, K., \& Belajar, H. (2015). Pengaruh konsep diri dan kebiasaan belajar terhadap hasil belajar matematika siswa kelas viii smp negeri 6 bontomatene kepulauan selayar, 3, 103-116.

Rahmawati, F., Sudarma, I. K., \& Sulastri, M. (2014). Hubungan Antara Pola Asuh Orang Tua Dan Kebiasaan Belajar Terhadap Prestasi Belajar Siswa Sd Kelas Iv Semester Genap Di Kecamatan Melaya-Jembrana, 2(1).

Sakaluk, J., Williams, A., \& Biernat, M. (2014). Perspectives on Psychological Science Psychological Science, (November). https://doi.org/10.1177/1745691 614549257

Siagian, R. E. F. (2012). Pengaruh Minat dan Kebiasaan Belajar Siswa Terhadap Prestasi Belajar Matematika. Jurnal Formatif, Vol 2(20), 122-131.

Triyono, T. (2017). KONTRIBUSI DUKUNGAN ORANGTUA TERHADAP TINGKAT ASPIRASI PENDIDIKAN LANJUTAN. Jurnal Pelangi, $8(2)$. 
Triyono, T., \& Febriani, R. D. (2018a). PENTINGNYA PEMANFAATAN

TEKNOLOGI INFORMASI OLEH GURU BIMBINGAN DAN KONSELING. JUANG: Jurnal Wahana Konseling, 1(2).
Triyono, T., \& Febriani, R. D. (2018b). Persepsi Peserta Didik Sekolah Menengah Atas Terhadap Pendidikan Lanjutan. Edudikara: Jurnal Pendidikan Dan Pembelajaran, 3(1), 70-77. 